\title{
Dysmagnesaemia and critical illness outcomes
}

\author{
LE Homer ${ }^{1}$, C Edmark ${ }^{2}$, KM Mogensen ${ }^{3}$, FK Gibbons ${ }^{4}$, KB Christopher $^{5^{*}}$ \\ From ESICM LIVES 2015 \\ Berlin, Germany. 3-7 October 2015
}

\section{Introduction}

The true impact of Magnesium derangement is unknown in critical illness. Conflicting reports in small studies have been published regarding mortality and dysmagnesaemia in critical care.

\section{Objectives}

We hypothesized that hypomagnesaemia would be associated with adverse outcomes following critical care.

\section{Methods}

We performed a two center observational study of patients treated in medical and surgical intensive care units in Boston, Massachusetts. All data was obtained from the Research Patient Data Registry at Partners HealthCare. We studied 81,061 patients, age $\geq 18$ years, who received critical care between 1997 and 2012 and who survived 72 hours following ICU admission. We excluded patients with End Stage Renal Disease. The exposure of interest was the lowest serum Magnesium measured in the 24 hours prior and 72 hours after ICU admission categorized a priori as $<1.4 \mathrm{mEq} / \mathrm{L}, 1.4-1.7 \mathrm{mEq} / \mathrm{L}$ and $>1.7$ $\mathrm{mEq} / \mathrm{L}$. The primary outcome was 30 -day all-cause mortality determined by the US Social Security Administration Death Master File. Adjusted odds ratios for 30-day mortality were estimated by multivariable logistic regression models with inclusion of terms for gender and the Acute Organ Failure score [[1]], a validated ICU risk-prediction score inclusive of terms for age, race, comorbidity, patient type (surgical vs medical), sepsis and acute organ failure.

\section{Results}

The cohort $(\mathrm{N}=81,061)$ had $58 \%$ men, $80 \%$ white race, $52 \%$ surgical patients, $12 \%$ with sepsis, and a mean age of 62 years. 30-day mortality was $9 \%$ and 30 -day hospital readmission was $14.2 \%$. In patients with magnesium $<1.4$ $\mathrm{mEq} / \mathrm{L}, 1.4-1.7 \mathrm{mEq} / \mathrm{L}$ and $>1.7 \mathrm{mEq} / \mathrm{L}$ the 30 day

\footnotetext{
${ }^{5}$ Brigham and Women's Hospital, Renal Division, Boston, MA, USA
}

Full list of author information is available at the end of the article mortality rate was $9 \%, 8 \%$ and $10 \%$ respectively. The adjusted odds of 30-day mortality in patients with $\mathrm{Mg}<$ $1.4 \mathrm{mEq} / \mathrm{L}$ was $0.94(95 \% \mathrm{CI} 0.87-1.01)$ and with $\mathrm{Mg}>1.7$ $\mathrm{mEq} / \mathrm{L}$ was $1.22(95 \% \mathrm{CI} 1.15-1.29)$, both relative to patients with $\mathrm{Mg} 1.4-1.7 \mathrm{mEq} / \mathrm{L}$. The AUC for the model was 0.79 indicating good discrimination for 30-day mortality. Further, in medical ICU patients $(\mathrm{N}=39,041)$, adjusted odds of 30-day mortality in patients with $\mathrm{Mg}<1.4 \mathrm{mEq} / \mathrm{L}$ was $1.02(95 \% \mathrm{CI} 0.92-1.13 ; \mathrm{P}=0.70)$ and with $\mathrm{Mg}>1.7$ $\mathrm{mEq} / \mathrm{L}$ was 1.45 (95\%CI 1.35-1.56; $\mathrm{P}<0.001)$, both relative to patients with $\mathrm{Mg}$ 1.4-1.7 mEq/L. Additional adjustment by acute kidney injury (RIFLE class injury or failure) or chronic kidney disease stage did not alter the Mgmortality association. Finally, in patients with nutrition status determined $(\mathrm{N}=6,923)$ there was no significant difference in serum $\mathrm{Mg}$ relative to nutrition status (ANOVA P-value $<0.001$ ).

\section{Conclusions}

In this large population of critically ill adults, hypermagnesaemia near ICU admission in medical ICU patients is associated with short term mortality. Hypomagnesaemia does not appear to be associated with adverse outcome.

\begin{abstract}
Authors' details
${ }^{1}$ University of Liverpool, Liverpool, United Kingdom. ${ }^{2}$ Karolinska University Hospital, Anaesthesiology, Critical Care and Surgical Services, Solna, Sweden. ${ }^{3}$ Brigham and Women's Hospital, Department of Nutrition, Boston, MA, USA. ${ }^{4}$ Massachusetts General Hospital, Pulmonary and Critical Care Medicine, Boston, MA, USA. ${ }^{5}$ Brigham and Women's Hospital, Renal Division, Boston, MA, USA.
\end{abstract}

Published: 1 October 2015

\section{Reference}

1. Elias KM, Moromizato T, Gibbons FK, Christopher KB: Derivation and validation of the acute organ failure score to predict outcome in critically ill patients: a cohort study. Crit Care Med 2015, 43(4):856-864.

doi:10.1186/2197-425X-3-S1-A499

Cite this article as: Homer et al:: Dysmagnesaemia and critical illness outcomes. Intensive Care Medicine Experimental 2015 3(Suppl 1):A499. (c) 2015 Homer et al.; This is an Open Access article distributed under the terms of the Creative Commons Attribution License (http:// creativecommons.org/licenses/by/4.0), which permits unrestricted use, distribution, and reproduction in any medium, provided the original work is properly cited. 